\title{
TTR
}

Traduction, terminologie, re?daction

\section{In memoriam Antoine Berman}

\section{S. S. et J.-M. G.}

Volume 4, numéro 2, 2e semestre 1991

Traduire la théorie

URI : https://id.erudit.org/iderudit/037090ar

DOI : https://doi.org/10.7202/037090ar

Aller au sommaire du numéro

\section{Éditeur(s)}

Association canadienne de traductologie

\section{ISSN}

0835-8443 (imprimé)

1708-2188 (numérique)

Découvrir la revue

Citer ce document

S., S. \& G., J.-M. (1991). In memoriam Antoine Berman. TTR, 4(2), 9-9.

https://doi.org/10.7202/037090ar d'utilisation que vous pouvez consulter en ligne.

https://apropos.erudit.org/fr/usagers/politique-dutilisation/ 


\section{In memoriam Antoine Berman}

Au moment de mettre sous presse, nous apprenons la disparition d'Antoine Berman, survenue le 22 novembre 1991 à Paris. Le monde de la traduction est en deuil de l'un de ses plus ardents et de ses plus lumineux penseurs.

Pour combien d'entre nous l'Épreuve de l'étranger, l'ouvrage majeur d'Antoine Berman, n'aura-t-il pas eu la puissance d'une véritable révélation. On y découvrait l'immensité et la richesse du territoire auquel ouvraient les études de la traduction. Les travaux ultérieurs d'A. Berman ont tenu la promesse du premier livre, alliant la pensée spéculative, les études de cas précis et un souci intense pour la pratique actuelle de la traduction. De son enthousiasme intellectuel se dégageait une énergie essentielle à notre discipline.

$T T R$ doit beaucoup au traductologue généreux qu'il fut. En 1986, alors que la revue n'était encore que dans les limbes, il n'avait pas hésité à répondre à notre appel de collaboration en proposant l'article «De la translation à la traduction» pour publication au premier numéro. unique.

Sa disparition brutale nous prive d'une source d'inspiration S.S. et J.-M.G. 